\title{
The Contribution of Metacognitive Skills and Reasoning Skills on Problem Solving Ability Based on Problem Based Learning (PBL) Model
}

\author{
Beni Setiawan \\ College of Teacher Training and Education (STKIP) Persada Khatulistiwa Sintang, Indonesia, \\ benisetiawan1892@gmail.com \\ Markus Iyus Supiandi \\ College of Teacher Training and Education (STKIP) Persada Khatulistiwa Sintang, Indonesia, \\ msupiandi@gmail.com
}

\begin{abstract}
The study of correlation between metacognitive skills and reasoning skills on problem solving ability simultaneously in class used PBL learning model is still less. This study aims to reveal the relationship between metacognitive skills and reasoning skills on problem solving ability of the students in STKIP Persada Khatulistiwa Sintang in learning mathematics used Problem Based Learning (PBL) model. This research involves 29 students of 3rd semester at Primary School Teacher Education Department. This research was a correlational research. Data were analyzed using multiple regression analysis. The result of analysis shows that there is a correlation between metacognitive skills and reasoning skills on problem solving ability of the student in learning mathematics based on Problem Based Learning (PBL) model. This is indicated by the significance value of $0.046<0.05$. This is also indicated by the number of contribution of metacognitive skills and reasoning skills toward problem solving abilities of $20.41 \%$ and $0.69 \%$. It appears that the relationship is an metacognitive skills and reasoning skills that has the greatest contribution to problem solving abilities.
\end{abstract}

Keywords: metacognitive skills, reasoning skills, problem solving ability, problem-based learning, learning mathematics

\section{INTRODUCTION}

The pattern of learning at various levels of education in Indonesia is still largely oriented towards conceptual mastery and has not pursued the empowerment of thinking skills including students' metacognitive skills. The same thing happened to lectures in the Primary School Teacher Education Department STKIP Persada Khatulistiwa Sintang which showed that lecturers have not fully attempted to empower metacognitive skills in lecturing. Corebima (2009) states that the empowerment of thinking and metacognition needs to be done so learners become independent learners. Livingston (1997) states that metacognition plays a critical role in successful learning. The lack of empowerment of students' metacognitive skills will have an impact on the low level of higher order thinking skills.

O'neil \& Brown (1997) states that metacognition as the process by which individuals think about their own thinking in order to develop strategies to solve problems. Metacognition refers to the skills of learners consciously in monitoring their learning process. Livingston (1997) states that metacognition refers to higher order thinking which involves active control over the cognitive processes engaged in learning. Furthermore, Gagne (1985) pointed out that metacognition is a high-level cognitive process

Citation: Setiawan, B., \& Supiandi, M. I. (2018). The Contribution of Metacognitive Skills and Reasoning Skills on Problem Solving Ability Based on Problem Based Learning (PBL) Model. Anatolian Journal of Education, 3(2), 7586. https://doi.org/10.29333/aje.2018.327a 
and also the ultimate goal of instructions. The goals of instructions are to deliver knowledge and also develop students' abilities to plan, monitor and even reorganize learning strategies. Students with good metacognitive skills are better critical thinkers, problem-solvers, or decision makers than students who are not. (Dawson, 2008). Suraya at al (2008) states that metacognition is one of the aspects that develop students in the math problem solving abilities. In addition to metacognition, reasoning skills are considered to play an important role in various types of cognitive activity. The activation of metacognitive skills can create self-learner which can influence the improvement of high order thinking ability (reasoning skills).

Reasoning is an activity or process of thinking to draw a conclusion or to make a new statement based on several statements known to be true or verified (Wardhani, 2004; Kusmaryono, 2013; Shadiq, 2014; Rohana, 2015). Lithner (2008) reasoning is defined as the line of thought adopted to produce assertions and reach conclusions in task solving. This means that this line of thought does not have to be based on formal logic; it could even be incorrect. Reasoning generally relates to the ability to find a problem solving.

Metacognitive skills and reasoning skills can be improved by applying some appropriate strategies or learning models. Some research findings reveal that metacognitive skills and reasoning skills can be improved by applying specific learning strategies or models. Adityas \& Saadi (2015) showed that the metacognitive activity based on PBL model had an effect on problem solving abilities. Sari at al (2017) reported that Problem Based Learning model combined with Numbered Heads Together (NHT) influence the metacognitive and critical thinking skills. Sungur \& Tekkaya (2006), Paidi (2008), Danial (2010), and Muhidin (2012) reported that the PBL model enable students to activate their metacognitive skills in the learning process. On the other hand Aprianti (2009), Nurmaningsih (2009) and Chairani (2015) report the study on metacognitive behavior in problem solving. Magno (2010) and $\mathrm{Ku}$ and $\mathrm{Ho}$ (2010) investigate the correlation between metacognitive skills and thinking skills. Wicaksono (2014) reported that there is a correlation between metacognitive skills and critical thinking on students' cognitive learning outcomes.

The previous researches studying on the effect, the relationship of one independent variable with dependent variable shows that there is an effect and relationship between metacognitive skills and problem solving ability and critical thinking ability. Furthermore, it needs a specific study that examines the correlation between two independent variables or more against one dependent variable. Because when the two independent variables are together, those are possible to give different effects on the dependent variable.

The correlational studies are used to study the relationship of two or more variables, in which variations in one variable relate to variations in other variables (Sudjana and Ibrahim, 2007). According to Emzir (2009), correlational research is applied for determining the relationship between independent variables with dependent variables, or for using these relationships to make certain predictions. Predicting a complex phenomenon using only one factor (independent variable) often only produces less accurate results. In many cases, the more accurate information we have the more accurate predictions can be made, for example, by combining two or more independent variables, the prediction of the dependent variable will be more accurate than just using each independent variable partly. Thus, the addition of the number of independent variables will increase the prediction accuracy of the dependent variable. Relationship studies usually investigate a number of variables that are believed to be related to major variables, for example if the problem-solving variable has no high relationship, it can be eliminated for further concern.

The description of the relationship or correlation between two independent variables or more against one dependent variable in this study can be seen using a learning model. The appropriate learning model to illustrate the relationship between metacognitive skills and reasoning skills on problem

Anatolian Journal of Education, October $2018 \bullet$ Vol.3, No.2 
solving abilities is a learning model that facilitates students to develop their own knowledge and apply their concepts by solving problems in learning. The learning model that is considered appropriate to apply is the Problem Based Learning model. Problem Based Learning Model (PBL) is based on learning not only the process of memorizing concepts or facts but also the process of interaction between individuals and their surroundings. Problem Based Learning models (PBL) can also develop the skills needed in the knowledge era (Tan, 2003) because they can develop higher order thinking skills such as critical thinking skills, problem-solving strategies, self-regulated learning, collaborative learning, and lifelong learning (Steck at al, 2012). Problem Based Learning (PBL) model can be applied in higher education level because PBL is based on problem, involving thinking activity to solve problem and correlating with cognitive function of learners (Izzaty, 2006). PBL potentially empower metacognitive skills (Ackay, 2009).

Mathematics courses are considered potentially used as a research material to improve problemsolving skills and conceptual skills. Mathematics is one of the most important subjects of science. Because of its importance, math is taught from elementary school level to college level. Math needs to be given to all learners to equip learners to be able to think logically, analytically, systematically, critically, creatively and to work together so that learners are capable to acquire, manage, and apply information to survive in an ever-changing, uncertain, and competitive condition (Permendiknas No. 22, 2006). Furthermore, Depdiknas (2006) pointed out that math needs to be taught to learners to be able to understand the concepts of mathematics and able to apply it in problem-solving activities.

Based on several correlation studies, the contribution of each factor can be revealed in problemsolving ability, metacognitive skills and reasoning skills, the simultaneous contribution of metacognitive skills and reasoning skills against problem-solving skills.

\section{METHOD}

\section{General Background of Research}

This study belongs to a descriptive correlational study. This correlational research attempts to explain whether there is a relationship between variables or not based on the value of the correlation coefficient. This research uses metacognitive skills and reasoning skills as independent variable, problem solving ability as dependent variable and Problem Based Learning (PBL) model as control variable. This research was conducted to reveal the contribution of metacognitive skills and reasoning skills toward problem solving ability based on Problem Based Learning (PBL) model in Primary School Teacher Education Department STKIP Persada Khatulistiwa Sintang.

\section{Sample of Research}

The sample used in this research is the students of 3rd semester of D6 class with the number of students as many as 29 students. Sampling technique uses purposive sampling. Before establishing the sample, the writer does the equivalence test based on daily test scores. Equivalence testing samples was done by using a different test criteria that there is no difference between the classes used ( $p>$ $0.05)$.

\section{Instrument and Procedures of Research}

The instrument used in this study consists of two things, namely instruments for learning devices and instruments for measuring research variables. Instruments for learning tools consist of: 1) Semester Lesson Plan (RPS), 2) Student Worksheet (LKM). Instruments for measuring the research variables consists of an essay test used to obtain data about metacognitive skills, reasoning skills and problemsolving abilities. The process of collecting data in this research begins doing pretest to know the 
metacognitive skills, reasoning skills, and problem solving abilities and running the learning process with Problem Based Learning (PBL) model and followed by giving posttest.

\section{Data Analysis}

This research data is data about metacognitive skills, reasoning skills and problem solving abilities collected through pretest and posttest. The difference value between pretest and posttest was analyzed using multiple regression analysis with SPSS 23.0 for Windows program. The analysis results are used to determine the multiple correlation between two criteria and one predictor. Before analyzing the multiple regressions, the data were firstly tested with the normality test data using KolmogorovSmirnov test.

\section{FINDINGS}

\section{Problem Based Learning Model}

The data in this research includes data of metacognitive skill, reasoning skill and problem-solving ability. These three data were obtained through pretest and posttest. The summary data from those three research results can be seen in Table 1.

Table 1

Summary of data on metacognitive skill, reasoning skill and problem-solving ability and their differences

\begin{tabular}{llllll}
\hline & N & Mean & Std. Deviation & Minimum & Maximum \\
\hline Metacognitive Skill & 29 & 45,4023 & 20,33093 & 15,45 & 85,64 \\
\hline Reasoning Skill & 29 & 73,4483 & 9,74938 & 58,69 & 93,63 \\
\hline Problem Solving Ability & 29 & 74,1379 & 18,67007 & 36,71 & 109,96 \\
\hline
\end{tabular}

Data obtained through the test were analyzed using multiple regression analysis. This type of analysis was chosen to determine the relationship between two independent variables (predictor) against one dependent variable (criteria). Analysis of data using multiple regressions should be preceded by normality test data using Kolmogorov-Smirnov test. The results of the normality test summary can be seen in Table 2.

Table 2

Summary results of normality test data on skill, reasoning skill and problem-solving ability

\begin{tabular}{lllll}
\hline & & $\begin{array}{l}\text { Metacognitive } \\
\text { Skill }\end{array}$ & \multirow{2}{*}{ Reasoning Skill } & Problem Solving Ability \\
\hline & $\mathrm{N}$ & 29 & 29 & 29 \\
\hline \multirow{2}{*}{$\begin{array}{l}\text { Normal } \\
\text { Parameters }\end{array}$} & Mean & 45,4023 & 73,4483 & 74,1379 \\
\cline { 2 - 5 } $\begin{array}{l}\text { Most Extreme } \\
\text { Differences }\end{array}$ & Std. Deviation & 20,33093 & 9,74938 & 18,67007 \\
\cline { 2 - 5 } & Absolute &, 142 &, 140 &, 210 \\
\cline { 2 - 5 } & Positive &, 142 &, 135 &, 100 \\
\cline { 2 - 5 } & Negative &,- 100 &,- 140 &,- 210 \\
\hline Test Statistic & &, 142 &, 140 &, 210 \\
\hline Asymp. Sig. (2-tailed) &, $138^{\mathrm{c}}$ &, $156^{\mathrm{c}}$ &, $002^{\mathrm{c}}$ \\
\hline
\end{tabular}

Normality test is to determine whether the distributed research data results are normal or not. The data is set to be normally distributed if the probability is counted $>0.05$ and not normally distributed if the probability count $<0.05$. Based on the results of normality test by using Kolmogorov-Smirnov test, it is known that normality test on metacognitive skill of 0.138 , reasoning ability of 0.156 and data problem solving ability of 0.002 . It can be concluded that the data in the study is normally distributed.

The summary of correlation of regression analysis between metacognitive skill and reasoning skill on problem solving ability by applying PBL learning model is presented in Table 3 to Table 6. 
Table 3

Summary of variance analysis of correlation between metacognitive skill and reasoning skill on problem solving ability by applying PBL model

\begin{tabular}{lllllll}
\hline \multicolumn{7}{c}{ ANOVA $^{\mathrm{a}}$} \\
\hline & Model & Sum of Squares & Df & Mean Square & F & Sig. \\
\hline 1 & Regression & 2058,357 & 2 & 1029,178 & 3,474 &, $046^{\mathrm{b}}$ \\
\cline { 2 - 7 } & Residual & 7701,645 & 26 & 296,217 & & \\
\cline { 2 - 5 } & Total & 9760,002 & 28 & & & \\
\hline
\end{tabular}

Based on the result of data analysis in Table 3 using multiple regression of correlation between metacognitive skill and reasoning skills on problem solving ability by applying of PBL learning, the results had an F-test value of 3.474 with significance value of $0,046<0.05$. It can be concluded that research hypothesis $\left(\mathrm{H}_{1}\right)$ is accepted and null hypothesis $\left(\mathrm{H}_{0}\right)$ is rejected. This suggests that there is a correlation between metacognitive skills and reasoning skills on problem-solving abilities. The B values of the two variables (metacognitive skill and reasoning skill) are presented in Table 4, and the constants are 73,908. It can be seen that the multiple regression equation is $\mathrm{y}=0.426 \mathrm{X} 1+-0.260 \mathrm{X} 2$.

Table 4

Regression coefficient of correlation between metacognitive skill and reasoning skill on problem solving ability with PBL model

\begin{tabular}{|c|c|c|c|c|c|c|}
\hline \multicolumn{7}{|c|}{ Coefficients $^{\mathrm{a}}$} \\
\hline & \multirow{2}{*}{ Model } & \multicolumn{2}{|c|}{$\begin{array}{l}\text { Unstandardized } \\
\text { Coefficients }\end{array}$} & \multirow{2}{*}{$\begin{array}{l}\text { Standardized } \\
\text { Coefficients } \\
\text { Beta }\end{array}$} & \multirow[t]{2}{*}{$\mathrm{t}$} & \multirow[t]{2}{*}{ Sig. } \\
\hline & & $\mathrm{B}$ & Std. Error & & & \\
\hline \multirow[t]{3}{*}{1} & (Constant) & 73,908 & 24,869 & & 2,972 & 006 \\
\hline & PBL Metacognitive Skill & 426 & 163 & ,464 & 2,620 &, 014 \\
\hline & PBL Reasoning Skill &,- 260 & ,339 &,- 136 &,- 767 &, 450 \\
\hline
\end{tabular}

Table 5 shows the correlation coefficient $(R)$ is 0459 with a value of reliability $\left(R^{2}\right)$ of 0211 . The correlation value of 0.459 shows a weak correlation between metacognitive skill and reasoning skill on problem solving ability. It also shows that metacognitive skill and reasoning skill contribute $21.10 \%$ in explaining problem-solving abilities, while the rest of $78.9 \%$ is explained by other factors beyond metacognitive skill and reasoning skill.

Table 5

Summary of multiple regression results correlation between metacognitive ability and reasoning ability to problem-solving ability with PBL model

\begin{tabular}{lllll}
\hline & \multicolumn{3}{c}{ Model Summary } \\
\hline Model & $\mathrm{R}$ & $\mathrm{R}$ Square & Adjusted R Square & Std. Error of the Estimate \\
\hline 1 &, $459^{\mathrm{a}}$ &, 211 &, 150 & 17,21096 \\
\hline
\end{tabular}

Table 6

Contribution of metacognitive skill and reasoning skill on problem solving skills with PBL model

\begin{tabular}{lll}
\hline Variable & $\mathrm{RC}(\%)$ & $\mathrm{EC}(\%)$ \\
\hline X1 (Metacognitive Skill) & 96,7 & 20,41 \\
X2 (Reasoning Skill) & 3,3 & 0,69 \\
\hline Total & 100 & 21,1 \\
\hline
\end{tabular}

Table 6 shows that metacognitive skill parameters provide an effective contribution of $20.41 \%$, while reasoning skill parameters provide an effective contribution of $0.69 \%$ on problem-solving abilities. 


\section{DISCUSSION}

Based on the results of hypothesis test, the results had an F-test value of 3.474 with significance value of $0,046<0.05$ which means there is a correlation between metacognitive skill and reasoning skill on problem solving ability by applying Problem Based Learning (PBL) model. The results of this study are in line with the results of the study of Hacker \& Dunlosky (2003), Yunus at al, (2008) and Ihsan (2016) which pointed out that one's ability to solve problems is influenced by metacognition skills. The correlation between metacognitive skill and reasoning skill on problem solving ability in this research is because metacognitive skill is an important matter in solving problems which include selfmonitoring and planning. Self-monitoring refers to an individual's ability to perform a direct examination of the problem-solving process. Planning involves certain complexity of problem-solving into sub-goals so they can be solved separately and sequentially to enrich the final completion. Mohammad (2003) stated that metacognitive experiences are more important to determine the achievement of problem-solving ability. Panaoura \& Philippou (2004) reported that consciousness and skill in metacognive self-checking play a role in solving problems. O'neil \& Brown (1997) defined that metacognition as the process by which individuals think about their own thinking in order to develop strategies to solve problems.

Metacognition ability is identified as an important factor in the problem-solving process (Brown, 1978; Flavel, 1979; Carr, 2010). This is in line with the results of Keiichi's research (2000) which stated that metacognitive plays an important role in problem solving and students were more skillful in problem solving if they possessed metacognitive knowledge. Foong (2002) stated that success in problem solving relates to students' disposition and monitoring of their own thinking processes and their metacognitive level. Metacognitive ability as a part of the self-regulated process, the ability to control their self-thinking process is at every stage of problem solving. Lee \& Fensham (1996) stated that metacognition ability consisting of planning, controlling and monitoring the implementation processes and evaluating processes play a very important role in the learning process. Metacognitive skill can help students to solve problems through effective planning which involves the process of knowing the problems that need to be solved and understanding the effective strategies to solve them. Desmita (2012) stated that metacognitive skills in learning process can be demonstrated by performing metacognitive activities such as planning on how to complete the task.

Metacognition is the awareness of one's thinking about his self-thinking process both about what to know and what to do. In terms of thinking about what to think related to students' awareness of their ability to solve problems. Metacognitive has two components, metacognitive knowledge and metacognitive skills. Metacognitive knowledge is concerned with declarative knowledge, procedural knowledge, and conditional knowledge in solving a problem (Veenman, 2006). While metacognitive skills are related to prediction skills, planning skills, monitoring skills, and evaluation skills (Mulbar, 2008). Such skills are metacognitive in nature (Livingston, 1997). By using metacognitive skills, students will be aware of their thinking processes and can evaluate the outcomes of their thinking processes so that students can devise appropriate strategies to solve problems (Pratiwi \& Budiarto, 2014). The results of this study confirmed that metacognitive skills contribute to problem solving skills so that teachers in the learning process should facilitate students with certain lessons that can develop students' metacognitive skills. Such learning process will lead the students into people who have the skill to solve problems, able to make informed decisions and become independent thinkers who are ready to live in real life.

Further, related to the relationship between reasoning skills and problem-solving ability with the application of PBL model, the reasoning skills and problem solving has a very important role to achieve the goals of education and the success of students in school. The results of this study are in line with the results of research conducted by Bjulan \& Kristiansand (2007) who reported that 
mathematical reasoning relating to making conjecture and proving can be supported with a problemsolving learning strategy. English (1994) stated that reasoning plays a significant role in problem solving. Kaur at al (2009) stated that the thinking process that can optimize problem-solving abilities is reasoning. Bjuland \& Kristiansand (2007) stated that reasoning has five interrelated processes in thinking activities which include: 1) sense making is closely related to the ability to construct problem schemes and present knowledge, 2) conjecturing is the activity of predicting a conclusion and factual theory, 3) convincing means performing a solution strategy based on the previous two processes, 4) reflecting is reevaluating activities of the three processes that have been done by looking back the relevance to the relevant theories, 5) generalizing is the final conclusion of the whole process which are then identified and generalized in a process. The results of this study show that reasoning ability has correlation to problem solving ability by applying PBL model.

One of the learning models that potentially empower problem solving abilities is Problem Based Learning (PBL). PBLs focus on challenges to make students think. Learning using the PBL model is similar to teaching metacognitive and critical thinking skills to students so it can indirectly develop students learning with PBL models of metacognitive skills and thinking ability (Arends, 2008; Book at al, 2016). According to Arends (2009), the goals of PBL include: 1) building broad and flexible knowledge base, 2) developing effective problem-solving skills, 3) developing self-directed, lifelong learning skills, 5) becoming effective collaborators, 6) becomes an internal motivation for learning. Further Tan (2004) mentioned the purpose of PBL is to make learners proficient in process skills, problem-solving skills and lifelong learning. Yuan at al (2008) stated that PBL allow learners to participate and deal with problem-solving situations in small group work during the learning process. PBL use the problem as a first step in collecting and integrating new knowledge (Muhson, 2009). PBL facilitates learners through real-world and authentic problem solving and integrating interdisciplinary knowledge (Keziah, 2010).

\section{CONCLUSION}

Based on the findings and discussions, it can be concluded that there is a correlation between metacognitive skill and reasoning skill on problem-solving ability with Problem-based Learning (PBL) model. In addition, it is known that the contribution of metacognitive skills on problem solving abilities is higher than the contribution of reasoning skills. Based on these facts, further research should reveal more about the correlation between metacognitive skills and reasoning skills on problem-solving abilities in different populations and instruments. Because of that, lecturers should consider empowering metacognitive skills and reasoning skills by applying appropriate learning models. This is because metacognitive skills and reasoning skills are important predictors for making successful learning. 


\section{REFERENCES}

Ackay, B. (2009). PBL in Science Education. Journal of Turkish Science Education, vol. 6, no. 1, 2009, pp. $26-36$.

Adityas, A.O and Saadi, P. (2015). Pengaruh Model Problem Based Learning (PBL) Berbasis Aktivitas Metakognisi Terhadap Kemampuan Memecahkan Masalah Kelarutan dan Hasil Kali Kelarutan pada Siswa Kelas XI SMA Negeri 2 Banjarmasin (Influence of Problem Based Learning (PBL) Model Based on Metacognition Activity Ability to Problem Solving Ability Solubility and Solubility Solution Result on Student of Class XI SMA Negeri 2 Banjarmasin). Quantum, Jurnal Inovasi Pendidikan Sains (Journal of Educational Science Innovation), Vol. 6, No. 2, Oct 2015, hlm. 11-12.

Aprianti, L. (2009). Perilaku Metakognisi Siswa dalam Pemecahan Masalah Matematika pada Siswa Kelas VII SMP Negeri 16 Pontianak (Student Metacognition Behavior in Mathematical Problem Solving at Grade VII Students of Junior High School 16 Pontianak). Unpublished master's thesis. Pontianak. FKIP UNTAN.

Arends, L. I. (2009). Learning to teach 9th edition, Mac Graw-Hill Company, U.S.

Arends, R. I. (2008). Learning to Teach (Belajar untuk Mengajar). Terjemahan Helly Prajitno Soetjipto \& Sri Mulyantini Soetjipto. Yogyakarta: Pustaka Belajar.

Bjuland, R and Kristiansand. (2007). Adult Students' Reasoning in Geometry: Teaching Mathematics through Collaborative Problem Solving in Teacher Education. The Montana Mathematics Enthusiast, Vol. 4, No.1. NCTM.

Brown, A. L. (1978). Knowing When, When, Where, and How to Remember: A Problem of Metacognition. In R.

Car, M. (2010). The Importance of Metacognition for Conceptual Change and Strategy Use in Mathematics. In H. S. Waters \& W. Schneider (Eds) Metacognition, Strategy Use, and Instruction (pp. 176-197), NY, NY: Guilford.

Chairani, Z. (2015). Perilaku Metakognisi Siswa dalam Pemecahan Masalah Matematika (Student Metacognition Behavior in Mathematical Problem Solving). Math Didactic: Jurnal Pendidikan Matematika (Journal of Mathematical Education), Vol. 1, No. 3, September-December 2015.

Corebima, A.D. (2009). Metacognitive Skills Measurement Integrated in Achievement Test. Makalah disajikan dalam Third International Conference on Science and Mathematics Education (CosMEd). Malaysia, 10-12 November.

Danial, M. (2010). Pengaruh strategi pembelajaran PBL dan Group Investigation terhadap metakognisi dan penguasaan konsep Kimia Dasar Mahasiswa Jurusan Biologi FMIPA UNM (Effect of PBL and Group Investigation learning on metacognition and concept comprehension in chemistry of students at Biology Department, Faculty of Mathematic and Science, State University of Makassar, Indonesia) (Unpublished doctoral dissertation). The State University of Malang, Indonesia.

Dawson, T.L. (2008). Metacognition and Learning in Adulthood. 2008. ODNI/CHCO/IC Leadership Development. Northampton, 23 Agustus. 
Depdiknas. (2006). Peraturan Menteri Pendidikan Nasional Republik Indonesia tentang Standar Isi dan Standar Kompetensi Lulusan untuk Satuan Pendidikan Dasar dan Menengah (Regulation of the Minister of National Education of the Republic of Indonesia on Standards of Content and Graduate Competency Standards for Basic and Secondary Education Units). Jakarta: Depdiknas.

Desmita. (2012). Psikologi Perkembangan Peserta Anak Didik (Psychology of Development of Students). Bandung: Remaja Rosdakarya.

Emzir. (2009). Metodologi Penelitian Pendidikan Kuantitatif dan Kualitatif (Research Methodology of Quantitative and Qualitative Education). Jakarta: Grafindo Raja Persada.

Flavel, J. H. (1979). Metacognition and Cognitive Monitoring: A New Area of Cognitive Development Inquiry. American Psychologist, 34, 906-911.

Foong, P.Y. (2002). Using Short Opend-Ended Mathematics Questions to Promote Thinking and Undestanding. National Institute of Education, Singapore [Online] Provided : http:/www.math.unipa.it/ grim/SiFoong. PDF.

Gagne. R.M. (1985). The Condition of Learning and Theory of Instruction. New York: College Publishing.

Hacker, D. J., \& Dunlosky, J. (2003). Not all metacognition is created equal. New Directions for Teaching and Learning, 95, 73-79

Ihsan, M. (2016). Pengaruh Metakognisi dan Motivasi terhadap Kemampuan Pemecahan Masalah Matematika Melalui Kreativitas Siswa Kelas VIII SMP Negeri di Kecamatan Kindang Kabupaten Bulukumba (Influence Metacognition and Motivation to Problem Solving of Mathematics through Student Creativity Class VIII Junior High School in Kindang District, Bulukumba Regency). AlKhwarizmi: Jurnal Pendidikan Matematika dan Ilmu Pengetahuan Alam (Al-Khwarizmi: Journal of Mathematics and Natural Sciences Education), Oktober 2016, Vol. 4, No. 2, hal. 129-140.

Izzaty, R.E. (2006). Problem-Based Learning dalam Pembelajaran di Perguruan Tinggi (ProblemBased Learning in Learning in Higher Education), Paradigma, vol. 1, no. 1, 2006, 77 - 83.

Kaur, B. \& Har, Y.B. (2009). Mathematical Problem Solving in Singapore Schools. In B Kaur at al (2009). Yearbook. Mathematical Problem Solving. Singapore: World Scientific.

Keiichi, S. (2000). Metacognition in Mathematics Education. Mathematics Education in Japan, JSME, Japan.

Keziah, A.A. (2010). A Comparative Study of PBL and Lecture-Based Learning in Secondary School Students' Motivation to Learn Science, International Journal of Science and Technology Education Research, vol. 1, no. 6, 2010, pp. 126 - 131.

Ku, K. Y., \& Ho, I. T. (2010). Metacognitive strategies that enhance critical thinking. Metacognition and Learning, 5(3), 251-267.

Kusmaryono. (2013). The Importance Of Mathematical Power In Mathematics Learning. International Conference On Mathematics, Science, And Education. Faculty of Mathematics and Natural Sciences Semarang State University.

Lee, K..W.L. and Fensham, P.F. (1996). A general strategy for solving high school electrochemistry problems. International Journal of Science Education, 18, 543-555. 
Lithner, J. (2008). A Research Framework for Creative and Imitative Reasoning. Educational Studies in Mathematies, 67 (3), 255-276.

$\begin{aligned} & \text { Livingston, } \quad \text { J.A. } \\ & \text { (http://www.gse.bufallo.edu/fas/shuell/cep564/metacog.htm, diakses tanggal }\end{aligned}$ 16 November, 2017). Magno, C. (2010). The role of metacognitive skills in developing critical thinking. Metacognition and Learning, 5(2), 137-156.

Mohammad, I.A.J. (2003). The Effect of Metacognitive Scaffholding and Cooperative Learning on Mathematics Performance and Mathematics Reasoning Among Fifth Grade Student in Jordan. [Online]. Provided:

http://search.yahoo.com/search?p=metacognitive+in+mathematics+education+journal\&fr=yfp-t$501 \&$ toggle $=1 \&$ cop $=m s s \& e i=U T F-8 \& v c=\& f p \_i p=I D$.

Muhiddin. (2012). Pengaruh integrasi PBL dengan pembelajaran kooperatif Jigsaw dan kemampuan akademik terhadap metakognisi, berpikir kritis, pemahaman konsep, dan retensi mahasiswa pada perkuliahan Biologi Dasar (Effect of PBL learning integrated with Cooperative Jigsaw and academic level on students' metacognition, critical thinking, concept comprehension, and retention in Basic Biology) (Unpublished doctoral dissertation). The State University of Malang, Indonesia.

Muhson, A. (2009). Peningkatan Minat Belajar dan Pemahaman Mahasiswa melalui Penerapan Problem-Based Learning (Improved Interest in Student Learning and Understanding through Problem Based Learning Implementation), Jurnal Kependidikan (Journal of Education), vol. 39, no. 2, 2009, pp. $171-182$.

Mulbar, U. (2008). Metakognisi Mahasiswa dalam Menyelesaikan Masalah Matematika (Student Metacognition in Problem Solving of Mathematical), Makalah disajikan pada seminar nasional di Bandung (Paper presented at national seminar in Bandung).

Nurmaningsih. (2009). Perilaku Metakognisi pada Siswa Kelas X SMA Berdasarkan Tingkat Kemampuan dalam Pemecahan Masalah Pola Bilangan (Metacognition Behavior in High School X Grade Students by Level of Problem Solving Ability Pattern of Numbers). Unpublished master's thesis. Pontianak. FKIP UNTAN.

O'Neil, H. F \& Brown, R. S. (1997). Differential Effects of Question Formats in Math Assessment on Metacognition and Affect, CRESST-CSE University of California, Los Angeles.

Paidi. (2008). Pengembangan perangkat pembelajaran biologi yang mengimplementasikan PBL dan strategi metakognisi, serta efektifitasnya terhadap kemampuan metakognitif, pemecahan masalah, dan penguasaan konsep biologi siswa SMA di Sleman Yogyakarta (Development of biology learning tools implementing PBL supported by metacognition strategy, and its effectivity on metacognitive ability, problem solving, biology concept comprehension of students at Senior High School Sleman, Yogyakarta, Indonesia) (Unpublished doctoral dissertation). The State University of Malang, Indonesia.

Panaoura, A., Philippou, G. (2004). The Measurement Of Young Pupils' Metacognitive Ability In Mathematics: The Case Of Self-Representation and Self-Evaluation. Department of Education, University of Cyprus.

Permendiknas. (2006). Permendiknas RI No. 22 Tahun 2006 tentang Standar Isi untuk Satuan Pendidikan Dasar dan Menengah (Regulation of the Minister of National Education of the Republic 
of Indonesia Number 22 of 2006 on Content Standards for Basic and Secondary Education Units). Jakarta.

Pratiwi, D. S., \& Budiarto, M. T. (2014). Profil Metakognisi Siswa SMP dalam Memecahkan Masalah Matematika Ditinjau dari Kemampuan Matematika Siswa (Profile of Metacognition of Junior High School Students in Problem Solving of Mathematical Viewed from Students' Math Ability). Surabaya: FMIPA Universitas Negeri Surabaya.

Rohana. (2015). Peningkatan Kemampuan Penalaran Matematis Mahasiswa Calon Guru Melalui Pembelajaran Reflektif (Improvement of Mathematical Reasoning Skills of Teachers through Reflective Learning). Infinity Jurnal Ilmiah Program Studi Matematika STKIP Siliwangi Bandung (Journal of Infinity Mathematics Study Program of STKIP Siliwangi Bandung), Vol. 4, No. 1, Februari 2015.

Sari, P. N., Budijanto, Amiruddin, A. (2017). Pengaruh Penerapan Model Pembelajaran Problem Based Learning dipadu Numbered Heads Together terhadap Keterampilan Metakognitif dan Kemampuan Berpikir Kritis Geografi Siswa SMA (Influence of Application of Problem Based Learning Model Combined Numbered Heads Together to Metacognitive Skills and Critical Thinking Ability Geography of High School Students). Jurnal Pendidikan: Teori, Penelitian, dan Pengembangan (Journal of Education: Theory, Research, and Development), Volume: 2 Nomor: 3 Bulan Maret 2017, Hal. 440-447.

Shadiq, F. (2014). Pembelajaran Matematika: Cara Meningkatkan Kemampuan Berpikir Siswa (Mathematics Learning: How to Improve Student Thinking Ability). Yogyakarta: Graha Ilmu.

Steck, T.R., DiBiase, W., Wang, C \& Boukhtiarov, A. (2012). The Use of Open-Ended PBL Scenarios in an Interdisciplinary Biotechnology Class: Evaluation of a PBL Course Across Three Years, Journal of Microbiology \& Biology Education, vol. 13, no. 1, 2012, pp. 2-10.

Sudjana \& Ibrahim. (2007). Penelitian dan Penilaian Pendidikan (Research and Educational Assessment). Bandung: Sinar Baru Algesindo.

Sungur, S., \& Tekkaya, C. (2006). Effect of PBL and traditional instruction on self-regulated learning. The Journal of Educational Research, 99 (5), 307-317.

Suraya, A., Yunus., Ali, W.Z.W. (2008). Metacognition and Motivation in Mathematical Problem Solving. The International Journal of Learning: Annual Review 15, No. 3.

Tan, O.S. (2003). Problem Based Learning Innovation. Using Problem to Power Learning in the 21st Century, Cengage Learning Asia Pte. Ltd., Singapore.

Tan, O.S. (2004). Cognition, Metacognition, and Problem Based Learning, In Tan, Oon Seng (Ed). Enhancing Thinking through Problem Based Learning Approaches, Thomson, Singapure.

Veenman, M.V.J. (2006). Metacognition and Learning: Conceptual and Methodological Considerations, Business Media, Inc.

Wardhani, S. (2004). Pembelajaran Matematika Kontekstual di SMP (Contextual Mathematics Learning in Junior High School). Yogyakarta: PPPG Matematika.

Wicaksono, A.G.C. (2014). Hubungan Keterampilan Metakognitif dan Berpikir Kritis terhadap Hasil Belajar Kognitif Siswa SMA pada Pembelajaran Biologi dengan Strategi Reciprocal Teaching (Correlation of Metacognitive Skills and Critical Thinking of Cognitive Learning Outcomes High 
School Students on Biology Learning with Reciprocal Teaching Strategies). Jurnal Pendidikan Sains (Journal of Science Education), Vol. 2, No. 2, Juni 2014, Hal 85-92.

Yuan, H., Kunaviktikul, W., Klunklin, A \& Williams, B.A. (2008). Promoting Critical Thinking Skills through PBL, Journal of Social Science and Humanities, vol. 2, no. 2, 2008, pp. 85-100.

Yunus, Suraya, A., Ali, W. (2008). Metacognition and Motivation in Mathematical Problem Solving. The International Journal of Learning: Annual Review 15, No. 3 (2008): 121-32. 